\title{
THE CHARTER AT WORK
}

\author{
CAMIEL HAMANS
}

\section{Introduction}

The relation between language and identity is a direct one, but at the same time is dynamic (cf. Extra and Gorter, 2007). For each individual human being language is unalienable part of his/herself. However, at the moment people share a language this relation also depends on the status of the group they belong to. Is the group the dominant group of a country the language will be described as a standard national language; does the group form a minority the language may be called a minority or regional language, a dialect, slang etc. The way speakers of a language perceive the relation between their identity and their own language may differ according to this status.

Till some decades ago only national languages counted, which had the effect that speakers of minority languages were seen as inferior and were supposed to give up their language. Quite often they did since they wanted to become part of the 'superior' group. So they gave up part of their identity in exchange for a shared national identity.

This situation is a result of $19^{\text {th }}$ century processes of European nation state formation, in which Herder's philosophical or ideological idea 'one language one state' echoed. Regional or minority languages and dialects which were not influential or powerful enough to become the official language ${ }^{1}$ of the nation

\footnotetext{
${ }^{1}$ It may be clear that languages do not have power or influence. Speakers or groups of speakers can have power or influence. Since the metonymic use of the word language as if it is a living organism or even a human being is so widespread that this usage has become more or less common, this practice is followed here.
} 
states that were established in that period, lost respect. So gradually they were threatened in their existence. Actually it was not only minority languages but the minorities themselves which had to fear for their existence. After all, minorities were considered to be a threat to the unity of the, often young, nation states. That is why several members of minorities decided to follow the path of assimilation and therefore gave up their own language.

It was the $20^{\text {th }}$ century which showed a different pattern for the first time ${ }^{2}$. It started with the leftist Second Spanish Republic (1931-1936) that did its best to recognize the identity of regional minorities. "In the second half of the XIXth century, a growing regional cultural and literary romanticism appeared, also in the regions where a vernacular language was spoken. At the same time, a social and cultural recognition of the specific identities of the territories concerned developed and this triggered a process towards a new and different territorial organisation. The political battles, and above all the civil wars of the XIXth and XXth centuries prevented a harmonious convergence of the two positions. During the second Spanish Republic (1931-1936), a statute of autonomy was approved by the Spanish Parliament for Catalonia in 1931 and for the Basque country in October 1936. In Galicia the process was not completed owing to the dramatic events of the 1936-1939 Civil War. The Franco regime represents a brutal interruption of the process of recognition and use of traditional regional or minority languages of Spain that had just started." (Expert's Report Spain 2005: 5).

One has to wait till 19 December 1966 before a next step was set. On that day the General Assembly of the United Nations adopted the International Covenant on Civil and Political Rights. Unfortunately it took another ten years before the Covenant went into force. This Covenant commits the states that ratified it, to respect the civil and political rights of individuals. Article 2.1 requires the states which take part in the Covenant to respect these rights "without distinction of any kind, such as race, colour, sex, language (italics $\mathrm{CH}$ ), religion, political or other opinion, national or social origin, property, birth or other status". The Covenant inspired the General Assembly to adopt a "Declaration on the Rights of Persons Belonging to National or Ethnic, Religious and Linguistic Minorities" in December 1992. This declaration stipulates the right to use ones "own minority language in private and public, freely and without interference or any form of discrimination" (Art. 2) clearly and explicitly for the first time (Hamans, 2006: 231).

\footnotetext{
${ }^{2}$ In the multiethnic and multilingual Habsburg monarchy there existed already a practice of translating official documents into the different languages of the empire from the middle of the $18^{\text {th }}$ century, but these languages were the 'standard' vernaculars of the different parts of the Austrian Empire and were the languages that later on became the national languages of new nation states (Wolf, 2015).
} 
But it was not only the General Assembly of the United Nations that became interested in the rights of minorities. The Organization for Security and Cooperation in Europe (OSCE) and especially its High Commissioner on National Minorities drafted a series of recommendations regarding the rights of minorities. In this respect the 1998 Oslo Recommendations Regarding the Linguistic rights of National Minorities is the most important document.

The Council of Europe also adopted two important international treaties concerning the (linguistic) rights on minorities, in cooperation with the European Union:

- The European Charter for Regional or Minority Languages (ECRM) (1992)

-The Framework Convention for the Protection of National Minorities (FCPNM) (1995) (see for the history of the Charter Hamans, 2006).

Since the Charter is the most explicit document about the linguistic rights of minorities, the rest of this paper is devoted to the working of the Charter.

\section{France}

France did not belong to the first signatories of the Charter. It only signed it, together with Iceland on 7 May 1999, more than a year after the Charter went into force (1 March 1998). It was during the 'cohabitation' of right wing president Chirac and leftist Lionel Jospin that France signed the Charter, which was very unusual in itself already since France has a long anti-diversity tradition of being opposed against minorities and minority languages. This is a result of the French revolution in which the equality of all citizens was proclaimed. So they should share one and the same language. In addition a multitude of languages would undermine the unity of the state according to the revolutionaries. In 1793 Bertrand Barrère, member of the Committee of Public Safety, launched a campaign against dialects and regional languages: "La monarchie avait des raisons de ressembler à la tour de Babel; dans la démocratie, laisser les citoyens ignorants de la langue nationale, incapables de contrôler le pouvoir, c'est trahir la patrie... Chez un peuple libre, la langue doit être une et la même pour tous." According to Barrère regional languages such as Breton, German, Italian and Basque were the languages of the counterrevolution, of superstition, of hatred, fanaticism and bigotry (Van der Elst and Van Rootselaar, 2004: 110).

\footnotetext{
3 'The monarchy had good reasons to resemble the Tower of Babel. Within a democracy it is betraying the motherland when the citizens are still ignorant of the national language and are not able to check the power. A free people should have one and the same language' (see http://shenan doahdavis.canalblog.com/archives/2012/06/14/24498193.html)
} 
In 1794 Abbé Gregoire presented a report to the National French Convention Rapport sur la Nécessité et les Moyens d'anéantir les Patois et d'universaliser $l^{\prime}$ Usage de la Langue française. ${ }^{4}$. Although Gregoire was less extreme in his negative feelings towards dialects and minority languages than Barrère, he nevertheless suggested that all dialects should be eradicated and that a national language should be imposed upon all French citizens and that is what happened. 'Since we want all our citizens to become part of one nation, we need a uniform language'(Van der Elst and Van Rootselaar, 204: 111), the strategy Gregoire promoted became the national program.

This ideological stance remained the linguistic program for France for the next two centuries. In the 1880's the then French minister of education Jules Ferry implemented a series of measures to further weaken the position of the regional languages. In schools signs appeared on which one could read 'no spitting or speaking Occitan (or Breton etc.)'. As Bernard Poignant in his 1998 report on the position of regional languages confirms, it was still the practice in school to punish children for speaking 'patois', dialect. Art. 30 of the 1851 Loi d'éducation française ,'French Teaching Law', showed explicitly how the official French ideology thought about dialects: "It is strictly forbidden to speak patois during classes or breaks". France was seen as the mother of culture in many parts of Europe and so this French example was followed even at some secondary schools in the southern provinces of the Netherlands, where the national language was of course Dutch, till the 1930's.

However, in March 1981 the socialist and later French president François Mitterand let out another sound in a pre-election speech: "The time has come to give the languages and cultures of France an official status. The time has come to open school doors wide for them, to create regional radio and TV stations to let them be broadcast, to ensure they play all the role they deserve in public life" . However, Mitterand was still president of the French republic when the Charter was opened for signatures. Maybe the fact that the political situation in 1992 was rather unstable and that he had to govern in a situation of 'cohabitation' with a rightist administration from 1993 on that prohibited France to sign the Charter immediately or at an early stage.

When Jospin took up the plan to sign the Charter he asked two political friends to draft a report on regional French language matters. These two specialists were Nicole Péry, advisor for regional language matters in his own office and Bernard Poignant, among others mayor of Quimper, the ancient capital of the most traditional region of Brittany. No wonder that the report (Poignant,

\footnotetext{
${ }^{4}$ Report on the necessity and means to annihilate the patois and to universalise the use of the French language

${ }^{5}$ https://en.wikipedia.org/wiki/Vergonha
} 
1998) proposed to accept the dialects of France as regional languages in terms of the Charter. The reaction of Jospin was more than positive: "Vive la France polyglotte"

However, the general reaction was far less positive. President Chirac asked the Constitutional Council for advice and their reaction was without any doubt and negative. Article 2 of the ten French constitution states clearly: "La langue de la République est le français", , which means that no other languages can be accepted. In addition, the Republic is one and indivisible, the French people are one and the same according to the law which means that no collective rights can be granted to any subgroup, defined by common origin, culture, language or belief. According to the Constitutional Council there are not minorities in France by definition, as the constitutional laws of France are incompatible with the recognition of minorities. ${ }^{8}$ Although the Council and the President may have thought that this was the end of the discussion, it was only the beginning.

So in 2008 then President Sarkozy took the initiative to change the French Constitution and now article 2 reads: "La langue de la République est le français, dans le respect des langues régionales qui font partie de notre patrimoine." ${ }^{\text {" This }}$ new wording opened perspectives for ratification and it was President Hollande who resumed the ratification process in 2013 again. During the following ratification debate, the French government reiterated that certain Charter provisions already, prior to ratification, comply with the French legal order and may constitute the basis of a public policy promoting regional languages. Against this background, several municipalities in Brittany, including the City of Rennes, have expressed their interest in applying the Charter. At a conference about the Charter in May 2013, the Council of Europe encouraged French local and regional authorities to apply Charter provisions according to their competences, possibly in the framework of partnerships with the Council of Europe. Following this, more than twenty local and regional authorities have signed a local charter containing Charter provisions. Such local initiatives will help to prepare the future implementation of the Charter without any doubt.

One cannot prove that it is the bare existence of the Charter which changed the French attitude towards regional and minority languages, and dialects, since for instance François Mitterand used the argument of linguistic rights already before the Charter was drafted, but the claim is clearly justified that the question whether France should join the Charter caused a discussion about linguistic mi-

\footnotetext{
6 'Long live polyglot France' (Hamans, 2006:234).

7 'The language of the Republic is French'.

${ }^{8}$ Décision n ${ }^{\circ}$ 99-412 DC du 15 juin 1999: http://www.conseil-constitutionnel.fr/conseil-consti tutionnel/francais/les-decisions/1999/99-412-dc/decision-n-99-412-dc-du-15-juin-1999.11825.html

9 'The language of the republic is French, while respecting the regional languages that are part of our heritage.'
} 
nority rights, which seems to go in a direction of acceptance of diversity and plurality. This does not imply that spitting in public will be accepted everywhere in France soon, but it may be expected that the negative attitude towards linguistic minority rights will decrease and may be even disappear.

\section{The Charter in Spain}

As said before Spain was the first modern nation state that proposed recognition of linguistic minority rights. the dictatorial fascist Franco regime stopped this process abruptly and oppressed anything they saw as an expression of minority aspirations. The unity of the country was so interpreted as if unity and uniformity were synonymous. Therefore it was forbidden to speak another language that standard Spanish, which is Castilian. Two small examples will do to show the effect:

Salomon Kroonenberg a Dutch geologist with a penchant for languages and linguistics tells in a recent book (2014: 290) how he as a young student went to Galicia in Spain in 1969, where he tried to speak Galician with the local people, since he did not know Spanish yet but was able to communicate in Galician. The peasants were happy with this. Since 'fala como nos' ('he speaks as we do'), but from official side he was told that he should 'hable cristiano' ('speak Christian'), by which was meant 'speak Spanish'. Three young priests who were so brave to speak Galician 'Gallego' with this foreigner were punished immediately and sent off, each of them to a different tiny hamlet in the mountains, when Kroonenberg was still around in Galicia.

The Basque linguist Itziar Laka described in an interview with Damir Cavar what the language situation in the Basque Country was when she was a young girl: "(...) I grew up in a place and a time where language was a constant and relentless issue: the dictator Francisco Franco was alive, his regime in full force.

There were many stories that had language at their heart when I grew up, too many to tell here. There was for instance the story of how grandmother Damiana, my father's mum, had spent a night in jail because she had been caught speaking Basque in the streets of Bilbao to an acquaintance who came from her village and could not speak Spanish. That night in jail left a mark that never went away. On my mother's side, there were books hidden first, then burnt, forbidden books whose crime was the language they were written in.

Even my school was clandestine and forbidden, it did not have a fixed location. We left in the morning with a book and a folding chair, to the home of whoever's turn it was. Then, for a week or so, the folding chairs would unfold in your living room and that would be school. I cannot thank enough the brave and unassuming women who taught us. They were truly risking it all in their quiet, 
humble, daily work. It is hard to explain what it is like to have your language forbidden. It definitely makes you very aware of it."10

This situation lasted till the end of the Franco regime and the first democratic and free elections of 1977. "The election results showed the strength of the nationalist and regionalist parties, especially in Catalonia and the Basque Country. (...) The effect was to initiate the regional structuring of Spain, at the same time as the constitutional debate was going on (...)" (State Report Spain, 2002: 4).

And so one reads in the 1978 Spanish Constitution that "the Constitution is based on the indissoluble unity of the Spanish nation, the common and indivisible homeland of all Spaniards, and recognises and guarantees the right to autonomy of the nationalities and regions which make it up and solidarity among all of them" (Article 2) (State Report Spain, 2002: 5). Seventeen autonomous regions or cities were recognised and were given different powers, sometimes even legislative powers.

The effect was that the new Spanish Constitution explicitly recognised the cohabitation of several languages in Spanish society. Article 3 states: "Castilian is the official Spanish language of the State. All Spaniards have the duty to learn it and the right to use it." But next to the official language there are co-official languages which are official in the respective autonomous communities (State Report Spain, 2002: 26). For instance, Basque is the co-official language in the Basque Country and Catalan is the co-official language in Catalonia.

All these linguistic rights have been granted to the speakers of the regional languages of Spain long before the Charter came into existence. So it seems more likely that the new Spanish Constitution had an influence on the Charter than vice versa.

However, the Charter, which was ratified by Spain in 2001, also has a certain influence on the linguistic rights of Spanish minorities. The Charter is not a non-binding instrument. The Council of Europe has neither power nor an army to force the parties which participate in it to obey its directives. However, part of the Charter is a monitoring process ${ }^{11}$. Each three years the State Parties to which the Charter applies, have to hand in a report about the situation of the linguistic minorities in their respective countries. Subsequently a permanent Committee of Experts checks the report, meets with official institutions of this country but

\footnotetext{
${ }^{10} \mathrm{http} / / /$ blog.linguistlist.org/fund-drive/featured-linguist-itziar-laka/

${ }^{11}$ Such a monitoring process is not devised specifically for the Charter. The implementation of the Framework Convention is also monitored by an independent advisory committee. Monitoring has become a more or less standard procedure when it comes to the implementation of international covenants and conventions. For instance the International Convention on the Elimination of All Forms of Racial Discrimination, adopted in 1965, also operates by means of a monitoring process in which a committee of 18 experts evaluate the progress that is made in a specific country regularly.
} 
especially with NGO's during an on the spot visit and drafts an evaluation report, on which the government may react. Finally the Committee of Ministers of the Council of Europe publishes a Recommendation in which it advices the national government to take certain measures. These recommendations are made public, just as the reports and the evaluation reports. Although the Council of Europe and its Committee of Ministers have no executive power, usually the public opinion reacts strongly on the opinion of the Council and so national governments quite often feel obliged to follow part of the recommendations at least.

In the case of Spain, the Committee of Experts in general was rather happy with the way the Spanish government and the authorities of the different autonomous regions took care of the linguistic rights of the minorities. Especially the detailed manner in which Spain reported - the third State Report, delivered in 2011, contains 995 pages and even presents the number of bilingual Basque-Spain drivers' licences ${ }^{12}$ - is seen as impressive, but this does not mean that experts do not dare to criticise Spain. For instance the way the rights of Basque speakers in the Autonomous Community of Navarre, a mixed region, were guaranteed was criticised several times. Although the Spanish authorities answered that a different approach would require amending the statute of the autonomous region and even the terms of ratification by Spain of the Charter, the regional 'parliament' of Navarre discussed the problem at length and came up with a suggestion for a solution.

In addition, the Committee of Experts complained about the lack of multilingualism, or bilingualism, among officials, civil servants and judges. Because of problems caused by legitimate career prospects it took the Spanish authorities some time to improve the language skills of officials, judges and so on in the different regions. In the most recent reports the Committee of Experts compliments the Spanish government on the achievements.

\section{The Charter in the Netherlands}

Before presenting some details about the working of the Charter in the Netherlands it may be useful to give some more specific information about the Charter itself. These are: the Charter is about regional and minority languages, and trans-national languages such as Yiddish or Roma, but the Charter does not

\footnotetext{
${ }^{12}$ Apparently the report aimed at completeness. At page 751, one page after the figures about bilingual drivers licenses, one finds that it is impossible to issue bilingual Basque-Spanish passports, since passports "are standard models that must comply with the Resolutions adopted by the Member States of the European Union, which do not provide for bilingual passports". This voluminous report was followed by a much shorter fourth report (2014) of only 181 pages.
} 
define what a regional or a minority language is. It is up to the participating parties, potentially all 48 member states of the Council of Europe, to present the regional or minority languages of their country which they want to be recognized and possibly to be supported and promoted by their national and regional authorities according to the Charter. The only provisos the Charter makes are that dialects of the national standard language cannot be accepted as regional languages. In addition languages of recent immigrants fall outside the scope of the Charter. Only languages which are spoken already for some time within a country and which have historic ties with this country can be accepted.

Moreover the Charter speaks about recognition of regional and minority languages only - this is recognition according to Part II - and recognition and support. The latter is Part III recognition. When a language is recognized by national authorities according to Part III the national government is hold responsible for the support and the promotion of this language, which means that at least 35 undertakings, out of a much bigger list, should be fulfilled. The measures to be taken may relate to education, media, press, justice, naming, culture etc.

Recognition according to Part II is recognition tout court and therefore is more or less symbolic.

In the Netherlands two standard languages are spoken: Dutch and Frisian. Frisian is the language of the province of Fryslân ('Friesland' in Dutch and English) and is not in use outside this northern province ${ }^{13}$. Frisian comes from a different historical origin than Dutch. However, the position of Frisian has been a matter of discussion for a long time, since Fryslân always was a part of the Netherlands and never was an independent country or autonomous region. In the $19^{\text {th }}$ century a romantic movement under the leadership of the brothers Halberstma came up which sought recognition for the special position and value of Frisian that was seen as a simple vernacular without any prestige so far, although all linguists were aware of the different history of Frisian.

The struggle of this Friese Beweging, 'Frisian Movement', gradually achieved any result. In 1937 a first amendment was adopted to the Primary Dutch Education Act which permitted teaching of a vernacular language as an optional subject. The amendment did not mention Frisian explicitly. In 1948 a similar amendment was adopted to the Secondary Dutch Education Act. In 1953 after serious riots in the Frisian capital of Ljouwert ('Leeuwarden' in Dutch) the Dutch Government accepted a report that suggested that the use of Frisian in court and in administrative matters should be permitted. Two years later Frisian was accepted as one of the languages of instruction in the first forms of primary schools in Fryslân.

${ }^{13}$ Outside the Netherlands, in Germany, two different forms of Frisian are still spoken by considerably small minorities. 
From these data it will be clear that the Dutch government did not wait till the arrival of the Charter to take measures with regard to the regional language Frisian, but so far it was only Frisian that attracted the attention of the authorities.

The Netherlands immediately signed the Charter at 5 November 1992. During the preparation of the ratification of the Charter regional organizations and authorities from another part of the country came up with a proposal for the recognition of Low Saxon, a regional language spoken in the North Eastern and Eastern part of the Netherlands and which is the same language as Plattdeutsch, Low German, which is spoken in the neighboring German federal states. As a consequence Low Saxon was recognized as a Part II regional language in $1996^{14}$, whereas Frisian received Part III recognition.

The political decision making process managed to attract the attention of the regional language association of the province of $\operatorname{Limburg}^{15}$, which is in the South-East of the country. This private association was able to alert the provincial government and together they were so keen that they could convince the deputy minister and the parliament. Limburger received recognition as a Part II regional language in $1997^{16}$.

The arguments the promoters of Low Saxon put forward are that Low Saxon is the same language as Plattdeutsch or Plattdü̈tsch, as the language is called by its own speakers, which is spoken at the other side of the German border. So Low Saxon is part of a language continuum which starts in the eastern part of the Netherlands and extends far into Germany. A similar argument was used for Limburger. The same language is spoken westward in the Belgian province of Limburg but also eastward in the German Rheinland. In addition, both languages never contributed to the standard Dutch language and thus cannot be considered to be dialects of Dutch. These points which were made by some senior dialectologists at the request of the different regional authorities appeared to be convincing.

However, some good personal relations may have also helped, as Frans Roer, former head of the department Libraries and Literature of the Ministry of OC\&W (Education, Culture \& Science) testified ${ }^{17}$. When the application for the recognition of Limburger arrived at the Ministry it was Roer who was asked to deal with it. Roer, a specialist in ancient languages who is born in Brunssum, a small town in the South Eastern part of Limburg, did not see any problem and advised to recognize Limburger as a regional language. His colleague at the

\footnotetext{
${ }^{14}$ See for the not always easy process of convincing the Dutch deputy minister of education and the parliament, Belemans (2009: 112-119) and Leyen (2011: 20-23).

${ }^{15}$ The capital of the province of Limburg, Maastricht, may be better known.

${ }^{16}$ See for a detailed description of this process of recognition Belemans (2009: 127-148).

${ }^{17}$ Personal communication 30 April 2010.
} 
Ministry of Foreign Affairs with whom he discussed this issue agreed with him. It must be said that she was also from Limburg, just as the Minister of Education, Culture and Science, Jo Ritzen. However, it was his deputy Jacob Kohnstamm who had no relation with Limburg whatsoever, who defended the recognition of Low Saxon and later on Limburger in parliament.

With the decision to grant recognition to Low Saxon and Limburger the discussion did not stop. Shortly after the Dutch decision to recognize Limburger, the Flemish authorities asked the secretary-general of the Nederlandse Taalunie, 'the Dutch Language Union', the Belgian sociolinguist Koen Jaspaert what his opinion was about a possible signing by Belgium of the Charter and possible Belgian recognition of Limburger in terms of the Charter.

Before going on with this story one should know a few things about the organization of the federal Belgian state and of the the Dutch Language Union. Belgium is a federation of a few autonomous regions of which Flanders is exclusively Dutch speaking. Language matters and education are delegated to the government and the parliament of the autonomous regions. This as a result of the language wars that have plagued Belgium for so many years. So the Flemish authorities are responsible for the position of the Dutch language in the Flanders region, which consists not only of the two provinces of Flanders but also of Antwerp, part of Brabant and the Belgium province of Limburg, so the whole monolingual Dutch speaking part of Belgium. However, the Flanders region cannot conduct its own foreign policy. Thus, when it comes to European treaties, it is the Belgium government which has to sign such an agreement, but the Belgian minister is only allowed to do so if the competent ministers of the respective regions agree. Belgium never signed the Charter, since the Flanders region objected.

Dutch is spoken in Suriname, Flanders and the Netherlands. That is why the governments of these two states and that of the autonomous Flanders region established an organization for the care and the promotion of the common language, the Nederlandse Taalunie, the Dutch Language Union.

Roer, who was in a regular contact with the officials of the Taalunie because of his administrative status and duties, never thought about consulting the Taalunie when he was asked to advice about the status of Low Saxon and of Limburger. According to his opinion, the Dutch Language Union deals with Dutch and the question was not about Dutch but about the recognition of two other languages of the Netherlands. Therefore the whole procedure of recognition was a competence of the national authorities of the Netherlands and not of the Taalunie. The then secretary-general of the Taalunie, Greetje van den Bergh, who was Dutch, did not care about the decision of the Dutch government ${ }^{18}$.

\footnotetext{
${ }^{18}$ Personal communication May 2010.
} 
That changed when in 1998 the Flemish linguist Koen Jaspaert became secretary-general. He was of the opinion that the Taalunie should have been consulted, even in the case of Frisian. He even might have advised negatively against recognition of Frisian, is Frans Roer's opinion.

Jaspaert clearly showed a negative attitude towards the application of the Charter to Belgium and towards the recognition of Limburger and other regional languages ${ }^{19}$ in the Dutch language area. He gave two arguments for his rejection. The first is that in all the relevant literature Limburger always was seen as a Dutch dialect by linguists, by official bodies as well as by its speakers. The other argument is that one can only have one mother tongue. At the moment this mother tongue is a recognized regional language the speaker does not count as a speaker of the official language, Dutch in this case, any longer. This last argument has been ridiculed from different sides. In an interview ${ }^{20}$ given in 2000 Jaspaert was astonished as this. What he wanted to say was that according to his opinion recognition of Limburger as a separate language could disrupt the balance in the Voerstreek, a small region of six villages in the Belgium province of Limburg that has been the scene of a fierce language battle. The region is enclosed by French speaking areas on three sides. Only because of the number of Dutch speakers in these villages the region has been allocated to the Dutch speaking province of Limburg and so to the autonomous federal region Flanders. So Jaspaert was scared that recognition of Limburger as a separate language would consequently diminish the number of Dutch speakers in the Voerstreek, a region for which Dutch language regime was fought so heavily. Since the number of speakers of a language is relevant in villages and towns at the FrenchDutch language border, it is the number of mother tongue speakers that decides to which language regime and thus to which region a village or town belongs. Jaspaert was scared that a decrease of the number of speakers of Dutch should imply a transfer of Flemish territory to the French opponents.

Jaspaert is not the only Belgian specialist or politician who opposes the Charter because of the fragile language compromise which pacified the language battle.

For instance, Yvo Peeters, one of the members of the committee of the Council of Europe that drafted the Charter in the 1980's and early 1990's, commented in an interview given on the occasion of the twentieth anniversary of the Charter (Kozhemyakov and Carlsson, 2012: 8) "I followed the parliamentary debate and the ratification process. Unfortunately as you know, since Belgium cannot ratify the Charter in reflection of its constitutional order, I could of

\footnotetext{
${ }^{19} \mathrm{http} / /$ taalunie.org/organisatie/raad-der-nederlandse-letteren/verslagen/erkenning-limburgs

${ }^{20}$ Quoted and summarized in Roders (2000), chapter 6: http://www.limburghuis.nl/Archief/ SCRIP_TIL.htm
} 
course not be involved in the implementation which I am sorry for but I followed it as one of the directors of the European Bureau for Lesser-Used Languages and from an EU point of view. (...) Belgium has reached a balanced situation with the federal constitution of 1993 after a century and a half of linguistic discrimination of the Dutch-speaking majority by the French-speaking minority. So the only genuine minority today in Belgium is the $1 \%$ German speakers. As long as the French speakers want that residual social upper strata, francophones and francophone immigrants in Flanders should be subject to the Charter, and Flanders cannot agree to ratification, because it would be regressive and restore the linguistic, social discrimination of the 19th century."

This is not exactly the same argument as that of Jaspaert's, but it resembles it. What Peeters expresses here is the general feeling of Flemish authorities. Since the Flemish are scared that a French speaking minority after official recognition of their language as a minority language would claim special rights, they are scared that this could harm the still precarious position of Flemish. After all, there are still French speaking elites in the big Flemish cities, although they become smaller and smaller and are mostly fluent in Flemish as well. But the problem is especially acute in the so called facilities municipalities around Brussels. Brussels is a bilingual town, with a majority of French speaking people, surrounded by municipalities where Flemish is the first language. However, speakers with French as a mother tongue can profit from special facilities there. At the moment the majority would not speak Flemish in this peripheral area any longer, the Flemish authorities are afraid that they have to give up this, Flemish, territory. After all, in Belgium language rights are more seen as territorial rather than as individual.

December 2013 the Belgium minister of Foreign Affairs Didier Reynders, answering a question posed by the French speaking member of parliament Josy Arents, who wanted to know whether Flanders finally would follow the example of the French speaking community and would be willing to recognize regional and minority languages and would be willing to sign and ratify the Charter, only could inform Arents that because of 'political reasons' Flanders would not allow the national minister to sign the Charter. ${ }^{21}$

The French Community accepted already a decree in which regional languages spoken at its territory are recognised and in which the use of these languages is encouraged, in December 1990.

The rejection by Jaspaert of the regional language status for Limburger did not have any direct effect on the status of Limburger, spoken in the Netherlands. However, when 22 February 2000 the Dutch senator Bierman asked a question

\footnotetext{
${ }^{21} \mathrm{https} / /$ www.lachambre.be/kvvcr/showpage.cfm?section=qrva\&language=nl\&cfm=qrvaXm 1.cfm?legislat $=53 \&$ dossierID $=53-\mathrm{b} 130-662-0582-2012201314187 . \mathrm{xml}$
} 
to the deputy-minister of education about a possible withdrawal of the recognition for Limburger, the deputy-minister Rik van der Ploeg answered that this would not happen, but that it would have been better if the Taalunie would have been asked for advice in this matter and that the recognition for Limburger was only granted since the authorities of the province deeply wanted their language to be recognised. So this recognition was not based on scientific research, but was only given to please the Limburger authorities ${ }^{22}$.

When a year later the authorities of the Dutch province of Zeeland, which is the most South-Western part of the country, applied for recognition of their language as a regional language Jaspaert and the Council of the Taalunie advised negatively ${ }^{23}$. This time the number of speakers of the national language did not play a role anymore. The main argument came from the definition of Dutch dialects as given by the dialectologist Jan Goossens who calls Dutch dialects 'dialects spoken within the territory where Dutch is the standard language and where there is not spoken any other directly related standard language, ${ }^{24}$. According to this definition all languages spoken in the Netherlands, may be even Frisian, should be called Dutch dialects.

The other argument is that these languages/dialects (co-)contributed to the creation of the national language. That most specialist who were consulted by the provincial authorities of the regions were Low-Saxon is spoken, of the province of Limburg and of Zeeland just came to an opposite conclusion was taken for granted.

Actually historical linguists suppose that the contribution of Low Saxon is very restricted - the Dutch reflexive zich 'self' seems to come from a Low Saxon origin - and that the contribution of Limburger, a tone language is nonexistent. The contribution of Zeeuws, the language of Zeeland, to the creation of the national language is much bigger because of the smaller distance between Zeeuws and Hollandish, the dialect of the western provinces of Holland that together with Brabantian forms the basis for modern standard Dutch. Nevertheless the opinion of the Dutch Language Union appeared so influential that Zeeuws never received recognition, not even under Part II.

The influence of the Charter on the Dutch, and even Belgian, debate is clear. Without the Charter Low Saxon and Limburger never would have received

\footnotetext{
${ }^{22} \mathrm{http}: / /$ www.eerstekamer.nl/schriftelijke_vraag/de_erkenning_van_het_limburgs_als/f=y.pdf

${ }^{23} \mathrm{http} / /$ taalunie.org/organisatie/raad-der-nederlandse-letteren/verslagen/advies-inzake-erkenni ng-zeeuws-als-regionale-taal

${ }^{24}$ This definition may work well as it is used as a working definition for an introduction into Dutch dialectology. As an absolute definition it shows certain shortcomings such as the fact that the same 'dialect' will be called a dialect of Dutch, as in the case of Low Saxon before the recognition, and as a dialect of German, as in the similar case of Plattdeutsch. All linguists and dialectologists agree that it is the same language/dialect.
} 
a special status. In Belgium the effect is still negative, but there seems to arise an awareness for language matters which goes further than a battle against French only.

Also the monitoring process had some positive effect in the Dutch situation. Even though the Dutch government recognized three regional languages, plus two transnational languages, the care, the encouragement and the promotion was carefully delegated to regional authorities. The Committee of Experts complained about this practice several times. A national government may of course delegate duties to regional or local authorities. However, this does not take away the responsibility according to the law. Where Low Saxon is spoken in (parts of) five provinces, the national government should formulate a national language policy with regard to regional languages. In this way, the regional authorities have guidelines which they can follow. They now lack an overall guidance. The Dutch government remained reluctant to take the responsibility and to come up with a coherent overall language policy. In the Second State Report (2003: 183/4)the Dutch government explicitly rejected the responsibility: "The Netherlands Government's policy consists of making local and regional authorities in the Low Saxon linguistic region primarily responsible for developing policy on Low Saxon in accordance with the obligations entered into under the European Charter. The emphasis and intensity of policy will vary from one province or municipality to another, depending on the situation of each Low Saxon dialect. The local and provincial authorities, which have an intimate knowledge of the needs in this area, have developed various new initiatives on Low Saxon since the committee of experts' visit."

The Committee of Experts did not feel satisfied with this reaction and kept complaining. Finally eight years later, in the Fourth State Report the Dutch Government $(2011,11 / 2)$ put a step forward. The Dutch government remained reluctant to formulate a national language policy, since it prefers a 'tailor made' approach. However, since Low Saxon is spoken in four provinces (and a few municipalities in the South-Eastern part of Friesland (Fryslân)) and since all these bodies follow their own policy, the national government suggested to install a Consultative Body for Low Saxon for the coordination and harmonization of measures, as far as necessary and desired. This suggestion was followed wholeheartedly by the different regional and local boards.

In 2004 the Committee, having taking note of the discussion about the status of Limburger and of the position taken by the Dutch Language Union, wanted "the Dutch Government to indicate what steps have been taken to ensure the recognition of Limburger." (Experts Netherlands 2004: 9) The Third State Report 2007 report did not mention the discussion with the Dutch Language Unions explicitly, but stated in art. 2.1 (p.37) that the Dutch authorities "wished 
to make clear that it regards the recognition of Limburger as an expression of the cultural wealth of the Netherlands". And with this politically correct remark the danger was eliminated that the recognition could be withdrawn.

\section{The Charter in Poland}

The last country in which the Charter operates and that will be discussed here briefly is Poland. Due to its different history Poland signed the Charter only 12 May 2003. It was a government lead by the social-democrat Leszek Miller which set this step. Next national-conservative PiS-governments were less interested in European matters and so one had to wait till the liberal-democrat Donald Tusk took over power before the Charter was put on the agenda of the Sejm and before the Polish parliament accepted ratification in February 2009. By ratifying the Charter Poland became the $24^{\text {th }}$ Council of Europe member state that backs the Charter, which means that from that moment on over half of the Council of Europe member states are party of the Charter.

Poland recognised no less than 15 languages, more than most of the other European Council member states. These languages are: Kashubian, as a regional language, Belorussian, Czech, Hebrew, Yiddish, Lithuanian, German, Armenian, Russian, Slovak and Ukrainian, as national minority languages, Karaim, Lemko, Romani and Tatar, as ethnic minority languages and again Hebrew, Yiddish, Karaim, Armenian and Romani as non-territorial languages ${ }^{25}$. Due to national law, the Polish ratification makes a difference between national and ethnic minorities and thus their languages. In terms of the Charter this has no special consequences.

Again due to national legislation in which it is forbidden to make a difference between minorities all the languages mentioned are placed at the Part III level of the Charter, which again is exceptional. Only some German Federal States recognized all their regional and minority languages at the same Part III level ${ }^{26}$.

By being so generous in recognizing minorities, Poland opposes 'the dominant trend in Central and Eastern Europe, where territorial accommodation is not the general policy how states deal with actual or potential ethnic conflicts' (Hogan-Brun and Wolf, 2003: 10, cf. also Kymlicka, 2002: 16/7). This may be why the Polish government reacted so vehemently as if it was offended and misunderstood in its good intentions when the Committee of Experts criticized some of the arguments Poland used by not recognizing more languages and when it

\footnotetext{
${ }^{25}$ Non-territorial is the same as what here before are called trans-national languages.

${ }^{26}$ There is also a country such as Cyprus that only recognizes Part II languages.
} 
suggested some extra measures should be taken to protect and promote recognized languages (Comments Poland 2011) ${ }^{27}$.

Maybe the Polish authorities wanted to take away the possible irritation their harsh tone may have caused. Otherwise it is difficult to understand why the Second Sate report (2015: 4) starts with such a long introductory statement about the exceptional way Poland deals with the Charter according to the opinion of the Committee of Experts and which can only be seen as a conciliatory gesture and an explanation to the experts after the undiplomatic words of 2011: "The Committee of Experts for The European Charter for Regional or Minority Languages has pointed out that the selection of provisions of The European Charter for Regional or Minority Languages which the Republic of Poland has decided to use regarding the minority and regional languages is an ambitious choice, because Poland has undertaken to implement the same measures towards all the languages. Additionally, only one signatory state has selected a number of languages greater than Poland. Most states would report a few languages and Poland has chosen 15 of them. This results from the principle of equality of all in respect of the law included in Article 32, passage 1 of the Constitution of the Republic of Poland, and from the right of everyone to be treated equally by the public authorities and, on the other hand, it is compliant with suggestions of minority and regional language users, submitted during consultation of ratification documents of the Charter. Accepting the European Charter for Regional or Minority Languages, Poland sees in this convention of the Council of Europe an extremely important instrument to support solutions used in our country before, aimed at protecting the minority and regional languages."

In addition, the Second State Report (2015) makes quite clear that the Polish authorities have thought about the remarks, questions and suggestions of the Committee of Experts and the recommendations of the Committee of Ministers. The question of possible recognition of Silesian offers a good example. In their 2011 report the experts write: "During the on-the-spot visit, the Committee of Experts was informed by representatives of associations from Upper Silesia of

${ }^{27}$ quick look at the Comments by the Polish Authorities (Comments Poland 2011) is enough to produce several examples of unusually blunt and undiplomatic language, such as "The specification: "especially in the Małopolskie Voivodeship" is not true" (2011: 108)," According to the Polish Government, the lack of kindergartens or schools providing education in some minority or regional languages resulting from the lack of interest in learning a language in such a form cannot constitute a basis for accusation that Polish authorities do not implement the provisions of the European Charter" (2011: 110), "The Polish Government cannot agree with the remarks included in this section" (2011: 111), "It should be stated that according to the Polish Government, the two sentences in this chapter lack consequence" (2011: 112), "The sentence "Still, the studies in Nysa are payable" is false" (p. 114) and "It is not true that there is no radio or TV channel broadcasting exclusively in Kashubian" (114) (italics CH), etc. 
the wish for Silesian to be recognised in Poland as a regional language. A parliamentary initiative has been started with a view to amending the Act on National and Ethnic Minorities and on the Regional Language to this effect. According to the Polish authorities, Silesian is a dialect of the Polish language. It has not been included in the instrument of ratification. Based on the information received, the Committee of Experts asks the Polish authorities to inform it about the outcome of the aforementioned parliamentary initiative in the next periodical report." (Experts Poland 2011 6/7)

The immediate reaction of the Polish government was very negative (Comments Poland 2011:107) and simply denied the existence of a Silesian language and therefore rejected all rights to Silesian: "Silesian dialect does not meet the conditions stipulated in the Charter provisions. Therefore, it should not be called a "language." The Polish Government suggests replacing the term "Silesian language" with "Silesian dialect" or "Silesian ethnolect." In addition the authorities refer to the common opinion among Polish linguists, which leads to a point of view similar to that of the secretary-general of the Dutch Language Union in the discussion about Dutch regional languages: "The statement of the Ministry of the Interior and Administration was confirmed in the opinion of 20 May 2011 by the Council for the Polish Language at the Polish Academy of Sciences, which according to Article 12 section 1 of the Polish Language Act of 7 October 1999 (Dz. U. No 90, item 999, as amended) is a consultative and advisory body on the use of the Polish language. Minister of the Interior and Administration requested from the Council for the Polish Language an explanation if the language used traditionally by the inhabitants of Upper Silesia should be treated as a dialect of the Polish language or a separate "Silesian language." The Council stated unanimously that almost all, if not all, Polish linguists would confirm that the language used by the inhabitant[s] of Upper Silesia constitutes a dialect of the Polish language, which according to article 27 of the Constitution is the official language in the Republic of Poland. Dialectologists would add that "the language that is traditionally used by the inhabitants of Upper Silesia" constitutes a part of a dialect of the Polish language. Therefore, it does not meet formal conditions stipulated in article 19, section 1, point 2 of the Act of 6 January 2005 on National and Ethnic Minorities and on the Regional Language, nor the European Charter for Regional or Minority Languages." (2011: 108)

This of course is not an adequate answer to the question raised by the Committee of Experts regarding the parliamentary initiative. Moreover the Committee of Experts is very careful in its choice of words and terms. It does not call Silesian a language or dialect. It only speaks about Silesian and the wish of regional associations that Silesian should be recognized as a regional language. One does not find the wording 'Silesian language' anywhere in the expert evaluation. Therefore it is hardly possible to replace this formulation with the sug- 
gested wording 'Silesian dialect' or 'Silesian ethnolect'. The recent, Second State Report (2015: 18) answers to the question more properly: "In the letter of March 30, 2012 (Print no. 567), a group of Polish MPs submitted to the Speaker of the Sejm of the Republic of Poland Ms. Ewa Kopacz, a deputies' bill on amending the Acton National and Ethnic Minorities and Regional Languages, as well as other acts. The project assumes, among others, assigning the status of a regional language to the Silesian dialect of the Polish language. On July 11, 2012, the bill was sent to the 1st reading in the Commission for National and Ethnic Minorities of the Sejm of the Republic of Poland. On August 30, 2012, 1 st reading of the bill before the Commission took place. At the session on December 4, 2012, the Council of Ministers discussed a Draft of the Government's opinion in respect of the deputy's bill on changing the Act on National and Ethnic Minorities and Regional Languages, as well as other acts (Print no. 567) (RM-140-89-12). As a result of the session, the Council of Ministers decided to take no position. Until drawing up this Report, the Sejm of the Republic of Poland did not complete the works on the bill." As may be clear from this answer the question is still open, although the Council for the Polish Language at the Polish Academy of Sciences still considers Silesian as a dialect of Polish. It is too much to claim that the reopening of this discussion is a direct effect of the formal status of the Charter in Poland, but it is quite clear that the legal force of the Charter supports possible claims of groups of speakers who want their language to be recognized in terms of the Charter.

There also are more direct results of the Charter. In their 2011 report (Experts Poland 2011) the experts note that for instance Kashubian is not used as a language of instruction in schools, only as a subject in school, that there is no Kashubian education available at pre-school level (2011: 40) and that in some companies there still are rules prohibiting the use of Kashubian, even between mother tongue speakers of the language (2011: 49). In addition the experts complained that the national authorities did not take their responsibilities. The care for regional languages is mainly delegated to regional and local authorities, just as in the Dutch case discussed before. In the 2015 Second State Report the Polish government explicitly acknowledges its own responsibility. The main tasks and duties are delegated, since regional and local governments are able to produce tailor made solutions. However, the national government produced leaflets and launched a campaign to promote regional and minority languages, in which the ministry sums up the profits of the use of regional or minority languages, the value of these languages in terms of national heritage and in which the ministry explains that parents can ask for education in the regional language without extra costs. Moreover, between 2011 and 2015 the threshold for regional and minority language rights in communities, which was $20 \%$ - a number which was rather high according to the opinion of the committee of Experts and was 
advised to be lowered to $10 \%$ - is now reduced to $10 \%$. In addition quite some more places in the Kashubian region now were granted the right to use Kashubian as an auxiliary language. This is not exactly what the experts argued for, since they do not use the notion auxiliary language; however, it is an improvement. One has to await the next Evaluation Report before we will learn what the opinion of the experts is about these new measurements and about the steps taken by Poland.

\section{Baltic States}

When the Baltic States became members of the EU in 2004 they had to fulfil the so called Copenhagen admission criteria, that are threefold and say that a new member state should meet the following requirements:

- political: stability of institutions guaranteeing democracy, the rule of law, human rights and respect for and protection of minorities;

- economic: a functioning market economy and the capacity to cope with competition and market forces;

- and ability to take on the obligations of membership.

Among the political criteria the respect for and protection of minorities is mentioned explicitly. Therefore one would expect that the EU also includes the linguistic rights of minorities and so should check whether linguistic minority rights in accession states are guaranteed before these states were accepted as new members. Unfortunately this is not the case. Moreover, one has to admit that the EU is not very successful in guaranteeing minority rights. See for instance the rights of Roma in quite some 'old' and 'new' member states. This is not the place to discuss minority rights in the EU, but from what follows it will be clear that, although the political criteria are the first to be mentioned in the list of Copenhagen criteria, they actually are seen as the least important ones.

The political situation in the Baltic States in 2004 was still a very difficult one, when they became members of the EU. Estonia, Latvia and Lithuania only regained independence in 1991 after the Fall of the Berlin Wall. Between 1940 and 1991 these countries were occupied and colonized by the Soviet Union, which implied massive immigration of Russian speakers especially to Estonia and Latvia. Lithuania is a different case, since in this country there still lives a considerable Polish minority. This is a result of a historical development: Poland and Lithuania once formed a commonwealth giving rise to one of the biggest countries in the history of Europe.

Before the Soviet occupation, the Baltic States only enjoyed freedom between the Two World Wars. Before that they belonged to Russia and especially in the $19^{\text {th }}$ century the Russian Empire tried to implement a policy of russification. 
As a consequence the Baltic States only could start their process of nation building from 1991 on. In Western Europe and parts of Central Europe this process of nation building was typical for the $19^{\text {th }}$ century. A certain ethno-linguistic nationalism is therefore an automatic but at the same time undesirable outcome, just as it was in $19^{\text {th }}$ century Western Europe. Especially in Estonia and Latvia, with its extensive Russian speaking minorities, it turned out nearly impossible to grant specific language rights to these groups. Especially since the Russian speaking minorities considered themselves superior till the independence and therefore also saw their language as an educated, powerful language with a much higher standard than Estonian or Latvian. Russian was the national and common language of the superpower Soviet Union and so by all means superior to the inferior then regional or minority vernaculars.

In addition, during the Russian and Soviet occupation there have been frequent attempts to eradicate the minority languages, in a similar way as it was done in $19^{\text {th }}$ century France. So, no wonder that after independence one of the first priorities of the new Baltic nation states was revitalizing their own national languages and not so much protecting and promoting the former 'colonial' languages.

Whereas in Western Europe there is a modern tendency to stress the special character and some times even autonomy of regions (Kymlicka, 2002: 3/4 and Hogan-Brun and Wolf, 2003: 10), the direction in Eastern Europe and the Baltic States is just in the other direction. In the old member states of the EU there is a tendency towards national federalism, whereas because of a different historical process the focus of the national policy in the new EU-states is on nation building. In Western Europe, the direction goes from $19^{\text {th }}$ and early $20^{\text {th }}$ century assimilation or exclusion towards an opposite, pluriformed, multicultural diversity. The policy of the Baltic States is directed towards a unified society to which the old slogan of Herder applies 'one nation, one language'. It is uniformity against pluriformity. (Kymlicka, 2002: 5-17).

Although the Charter is a product of the Council of Europe, which is with its 47 member states far less Brussels-oriented than the EU, nevertheless the Charter is a clear product of a period in which Western European ideas and ideological stances were predominant. That is why countries such as the Baltic States, that due to historical reasons still have to focus on a $19^{\text {th }}$ century political goal such as nation building can not accept the Charter at this very moment, which of course is a pity since the languages of their minorities deserve protection, being Russian speaking or not. Actually it is an ideological antithesis: in Western European democracies have learned, or at least try to understand, in the last thirty years that ethno-cultural diversity is the only way to cope with internal oppositions (Kymlicka, 2002: 3), whereas in the Baltic States and some other Central 
European countries a nationalistic ideology, a strive for an national thought is prevalent ${ }^{28}$.

Moreover national minorities quite often were and are regarded as a hotbed for seperatism (Kymlicka, 2002: 19-21), as a threat for the national unity and security and sometimes even as being a 'fifth column' more cooperative with the enemies of the nation state than with the nation state. In the current situation in which the Russian government seems to be more interested in supporting Russian minorities in other countries than in respecting the national integrity of its neighbors, it is not a surprise that the priority of the governments of the Baltic states is not to grant and to promote the rights of these minorities. This of course is understandable, however much it is regrettable that linguistic minority rights are not well respected. Maybe signing of the Charter and consequently discussing possible ways of respecting the rights of minorities without necessary damaging a process of nation building could have shown a way how to combine these two together almost exclusive political goals. It is a pity that the governments of the Baltic States did not consider the Charter and especially its Committee of Experts as an aid and support and preferred to see the Charter as a threat. Unfortunately the Baltic States are not the only countries with internal language problems which did not feel free to grasp the outstretched hand of the Charter. As we have seen Belgium reacted in the same way, just as for instance Greece.

\section{Conclusions}

The examples given and discussed above show that the Charter has a certain influence, although the Committee of Ministers of the Council of Europe has no means to enforce implementation of the its recommendations and the suggestions of the Committee of experts. Since the public opinion is informed about the recommendations and suggestions, the national political authorities have to pay attention to these advices. Normally a public debate follows and quite often this is effective in reaching the goals formulated by the Committees.

Moreover the Secretary General of the Council of Europe reports on the application of the Charter in a detailed report each two years. This ensures that the members of the parliaments of all the member states of the Council of Europe are kept informed about the application of the Charter, enabling them to bring political pressure to bear, if necessary, to encourage national governments to take appropriate measures ${ }^{29}$.

\footnotetext{
${ }^{28}$ See for the $19^{\text {th }}$ century ideological nationalistic debate among others Leersen (2007).

${ }^{29}$ In his last report (March 2014) the Secretary General writes about the impact of the Charter: "The Charter and its monitoring mechanism continue to have positive effects on the situation
} 
In addition, since groups and NGO's of regional, minority and trans-national language speakers are aware of the existence, the content and the possible impact of the Charter, the Charter backs and supports them in their requests or fights for recognition and support. The Charter can be a powerful legal tool in the hands of NGO's or organized groups of speakers and so the adoption of the Charter should be described as a major step forwards in the recognition of linguistic minority rights in Europe.

Unfortunately, the Charter does not work yet in the way it could and should in parts of Central and Eastern Europe. In these most often young countries that still have to undergo a process of nation building, the Charter maybe helpful in order to prevent the exclusion of linguistic minority groups during this process of nation building. It is up to the Council of Europe and its Committee of Ministers to show the possibilities the Charter has to offer for these countries and to promote the Charter in this way.

\section{References}

Belemans, R. 2009. Taal of Tongval. De gespleten Limburgse Kus. Oraal erfgoed en taalpolitiek. Brussels: Pharo.

Elst, A. van der and F. van Rootselaar. 2004. Franse affaires. Frankrijk in twintig kwesties. Diemen: Veen Magazines/Filosofie Magazine.

Extra, G. and D. Gorter. 2007. "Regional and immigrant languages in Europe". In: Hellinger, M. and A. Pauwels. (eds.) Language and communication: diversity and change. Handbook of applied linguistics. Vol 9, Part 1. Berlin: Mouton de Gruyter. 15-52.

Hamans, C. 2006. "The minority language debate: the case of Yiddish in the Dutch language landscape". Werkwinkel. A Journal of Low Countries and South African Studies. 1.1. 225-252.

Hogan-Brun, G. and S. Wolff. 2003. Minority languages in Europe. Frameworks, status, prospects. Basingstoke/New York: Pallgrave Macmillan.

Hout, R. Van. 2007. "Wordt het Limburgs verwaarloosd door de Nederlandse overhead". In: Heyenrath, L. (ed.). Veldeke Jaarboek. Roermond: Veldeke Limburg. 42-44.

Kozhemyakov, A. and N. Carlsson. 2012. Mission possible. Looking back at the making of the Charter of Regional and Minority Languages. Strasbourg: Council of Europe: http://www. coe.int/t/dg4/education/minlang/Source/Publications/Missionpossible.pdf

of regional or minority languages in Europe. Examples of the Charter's impact comprise Sweden's Act on National Minorities and National Minority Languages which puts an obligation on the public sector to protect and promote the languages of the national minorities. In Spain, Aranese has been granted the status of a co-official language in the whole territory of Catalonia. Ukraine has adopted the Law "On the Principles of State Language Policy", replacing the former Soviet language law of 1989. The Free State of Saxony (Germany) implements an action plan to encourage the use of the Sorbian language in public life. In the Netherlands, Frisian speakers have the right to use their language in court even outside the Province of Friesland. The high legal status that Serbia has granted to Romani under the Charter (Part III) has contributed to improving the largely negative public image of this language and prepares its co-official use by municipalities." (2014:3) 
Kroonenberg, S. 2014. De Binnenplaats van Babel. Het Raadsel van de Spraakverwarring. Amsterdam/Antwerpen: Atlas Contact.

Kymlicka, W. 2002. "Multiculturalism and minority rights: West and East". JEMIE, Journal on Ethnopolitics and Minority Issues in Europe 4. 1-25.

Leersen, J. 2007. National thought in Europe: a cultural history. Amsterdam: Amsterdam University Press.

Leyen, F. 2011. Streektaalbeleid in Nederland. Unpublished Master thesis. Utrecht: RUU, Utrecht University.

Poignant, B. 1998. Langues et cultures régionales: Rapport au Premier Ministre. Paris: La Documentation Française (Collection des Rapports Officiels).

Wolf, M. 2015. The Habsburg Monarchy's many-languaged soul: translating and interpreting 1848-1918. Translated by Kate Sturge. Amsterdam/Philadelphia: John Benjamins.

\section{Web sources}

Monitoring reports European Charter for Regional or Minority Languages

Netherlands

$1^{\text {st }}$ Monitoring Cycle (1999-2001)

State Periodical Report

http://www.coe.int/t/dg4/education/minlang/Report/PeriodicalReports/NetherlandsPR1_en.pdf

Committee of Experts evaluation report

http://www.coe.int/t/dg4/education/minlang/Report/EvaluationReports/NetherlandsECRML1_en.pdf

$2^{\text {nd }}$ Monitoring Cycle (2003-4)

State Periodical Report

http://www.coe.int/t/dg4/education/minlang/Report/PeriodicalReports/NetherlandsPR2_en.pdf

$3^{\text {rd }}$ Monitoring Cycle (2007)

State Periodical Report

http://www.coe.int/t/dg4/education/minlang/Report/PeriodicalReports/NetherlandsPR3_en.pdf

$4^{\text {th }}$ Monitoring Cycle (2011)

State Periodical Report

http://www.coe.int/t/dg4/education/minlang/Report/PeriodicalReports/NetherlandsPR4_en.pdf

Poland

$1^{\text {st }}$ Monitoring Cycle (2010-2011)

State Periodical Report

http://www.coe.int/t/dg4/education/minlang/Report/PeriodicalReports/PolandPR1Annexe1_en.pdf Committee of Experts evaluation report:

http://www.coe.int/t/dg4/education/minlang/Report/EvaluationReports/PolandECRML1_en.pdf

Comments on the Committee of Experts' Report on the European Charter for Regional or Minority

Languages of 5 May 2011

http://www.coe.int/t/dg4/education/minlang/Report/EvaluationReports/PolandECRML1_en.pdf: $107-116$

$2^{\text {nd }}$ Monitoring Cycle (2015)

State Periodical Report

http://www.coe.int/t/dg4/education/minlang/Report/PeriodicalReports/PolandPR2_en.pdf 
Spain

$1^{\text {st }}$ Monitoring Cycle (2002-2005)

State Periodical Report

http://www.coe.int/t/dg4/education/minlang/Report/PeriodicalReports/SpainPR1_en.pdf

Committee of Experts evaluation report

http://www.coe.int/t/dg4/education/minlang/Report/EvaluationReports/SpainECRML1_en.pdf

$2^{\text {nd }}$ Monitoring Cycle (2007/8)

State Periodical Report

http:/www.coe.int/t/dg4/education/minlang/Report/PeriodicalReports/SpainPR2_en.pdf

Committee of Experts evaluation report

http://www.coe.int/t/dg4/education/minlang/Report/EvaluationReports/SpainECRML2_en.pdf

$3^{\text {rd }}$ Monitoring Cycle (2010-2012)

http://www.coe.int/t/dg4/education/minlang/Report/PeriodicalReports/SpainPR3_es.pdf

Biennial Report Secretary General

$7^{\text {th }}$ Biennial Report by the Secretary General of the Council of Europe to the Parliamentary Assembly (2014)

http://www.coe.int/t/dg4/education/minlang/sgreports/SGReport2013_en.pdf 